\title{
Field data and regional modeling of sediment supply to Emilia-Romagna's river mouths
}

\author{
Silvia Cilli ${ }^{1, *}$, Paolo Billi ${ }^{2}$, Leonardo Schippa ${ }^{3}$, Edoardo Grottoli $^{1}$, and Paolo Ciavola ${ }^{1}$ \\ ${ }^{1}$ Department of Physics and Earth Sciences, University of Ferrara, Italy. \\ ${ }^{2}$ International Platform for Dryland Research and Education (IPDRE), Tottori University, Japan. \\ ${ }^{3}$ Department of Engineering, University of Ferrara, Ferrara, Italy.
}

\begin{abstract}
The Fiumi Uniti and Savio rivers are two small sandy-bed river systems which sediment yield contributes feeds part of the EmiliaRomagna beaches (Italy). Since the twentieth century the northern Adriatic coast has been affected by well-known beach retreat phenomena. As the sediment supply of these local rivers is not well known, an analysis of bedload transport rates for the last 10 kilometres of the river has been done. Multiple analysis, supported by direct field measurements of the 2005-06 and 2017 years (still ongoing) have been realized. Complementary hydraulic investigation and modelling have been performed. Repeated bedmaterial samplings have been carried out during different flood conditions, obtaining a significant number of observations. Aiming at defining the behaviour of sediment-transport in these two rivers, this paper focuses on the analysis of threshold sediment transport condition. Several formulae available in literature were used to test the field measurements. All these criteria seem inappropriate to predict the threshold conditions for bed particle entrainment in terms of the value of bed shear stress. The inaccurate estimation given by these formulae is due to the fact that they do not consider natural grain-shape factors or are mainly suitable for gravel-bed rivers.
\end{abstract}

\section{Introduction}

During the last decades the coast of the Emilia-Romagna region has been affected by a considerable beach retreat phenomena. Given the relevant economic role of the summer tourism, beach protection and reconstruction became crucial for, coastal management $[1,2]$. In this region beach erosion is primarily due to the scarcity of sediment supplied by the small local rivers. The importance of small rivers in contributing both to beach stability and marine sedimentation has been previously pointed out for many of the world's coastlines $[3,4]$. Many factors contributed to the decrease in sediment supply and among them, anthropogenic interventions, such as an increase in deforestation, a change in land use, river bed mining and proliferation of dams, are the most evident $[5,6,7,8,9,10,11]$. Moreover, variations due to climate change such as decreasing of precipitation, runoff and water discharge, directly affected fluvial geomorphology and sediment supply [12].

*Corresponding author: silvia.cilli@unife.it 
Unfortunately, information about the sediment transport of Emilia-Romagna rivers is limited and restricted to a small number of them $[13,14,15,16]$. In order to enlarge the existing sediment supply dataset, bedload measurement campaigns in representative rivers have been carried out by the authors. Complementary hydrological investigations and hydraulic modeling are ongoing, aiming to define the sediment supply to the whole EmiliaRomagna coast. Since the prediction of the threshold conditions for sediment transport is crucial in modeling the river sediment yield, this paper focuses on this aspect with preliminary results of the undergoing investigations. For this purpose, a wide review of existing bedload field data has been carried out, including new data measured in a recent campaign.

\section{Study area}

The Fiumi Uniti and the Savio are two small river systems located in the southern part of the Emilia-Romagna region (Italy). The Fiumi Uniti, resulting from the unification of the Montone and Ronco rivers, drains the northern Apennines and has a catchment area of about $1000 \mathrm{~km}^{2}$ (Fig.1). The river crosses the city of Cesena and enters the Adriatic Sea between Lido Adriano and Lido di Dante, south of Ravenna (Fig.1). The Savio river (catchment area $645 \mathrm{~km}^{2}$ ), flows from the Apennines outflowing into the Adriatic Sea between Lido di Classe e Lido di Savio, close to Savio village, south of the former river (Fig.1).

The upper catchment of both rivers is underlained by Miocene turbidities consisting of sandstones and marlstones alternation [17]. Alluvial plain deposits consist mainly of Pliocene marine deposits and Quaternary Po river deposits [17]. The climate is typically Mediterranean [18]. Summer is typically dry and precipitation peaks are visible in March and October-November. The annual precipitation rate is $1025 \mathrm{~mm}$ and $961.43 \mathrm{~mm}$ for the Fiumi Uniti and the Savio, respectively. The mean temperature is practically the same, 13.5 and $13.6{ }^{\circ} \mathrm{C}$.

In the downstream reach of both rivers hydraulic infrastructures such as sluice gate dams are present. Along the Fiumi Uniti river, the Rasponi sluice gate, located $3.5 \mathrm{~km}$ upstream the river outlet, is used to retain water and to prevent upstream salt water migration (Fig.1). The Montone and Ronco river tributaries have two dams (San Marco and San Bartolo), located respectively at around $2.8 \mathrm{~km}$ and $4 \mathrm{~km}$ upstream the confluence (Fig.1). Similarly, the Castiglione dam on the Savio river is located $12 \mathrm{~km}$ upstream of the river mouth (Fig.1). Since all these dams are mainly used for agricultural purposes, the local Land Reclamation Authority (Consorzio di bonifica) keeps them completely opened during the flooding season (i.e. from October to March) and closed, during the dry period (from April to September).

The sediment transport monitoring sites are located in the terminal reaches of both rivers, where they have a sandy bed. The monitoring station of the Fiumi Uniti river is located in Ravenna (Fig. 2) in correspondence of a suspended pedestrian bridge, almost $8 \mathrm{~km}$ upstream of the river outlet. The Savio river's station is located on a road bridge, $3.5 \mathrm{~km}$ upstream from the outlet (Fig. 2). 


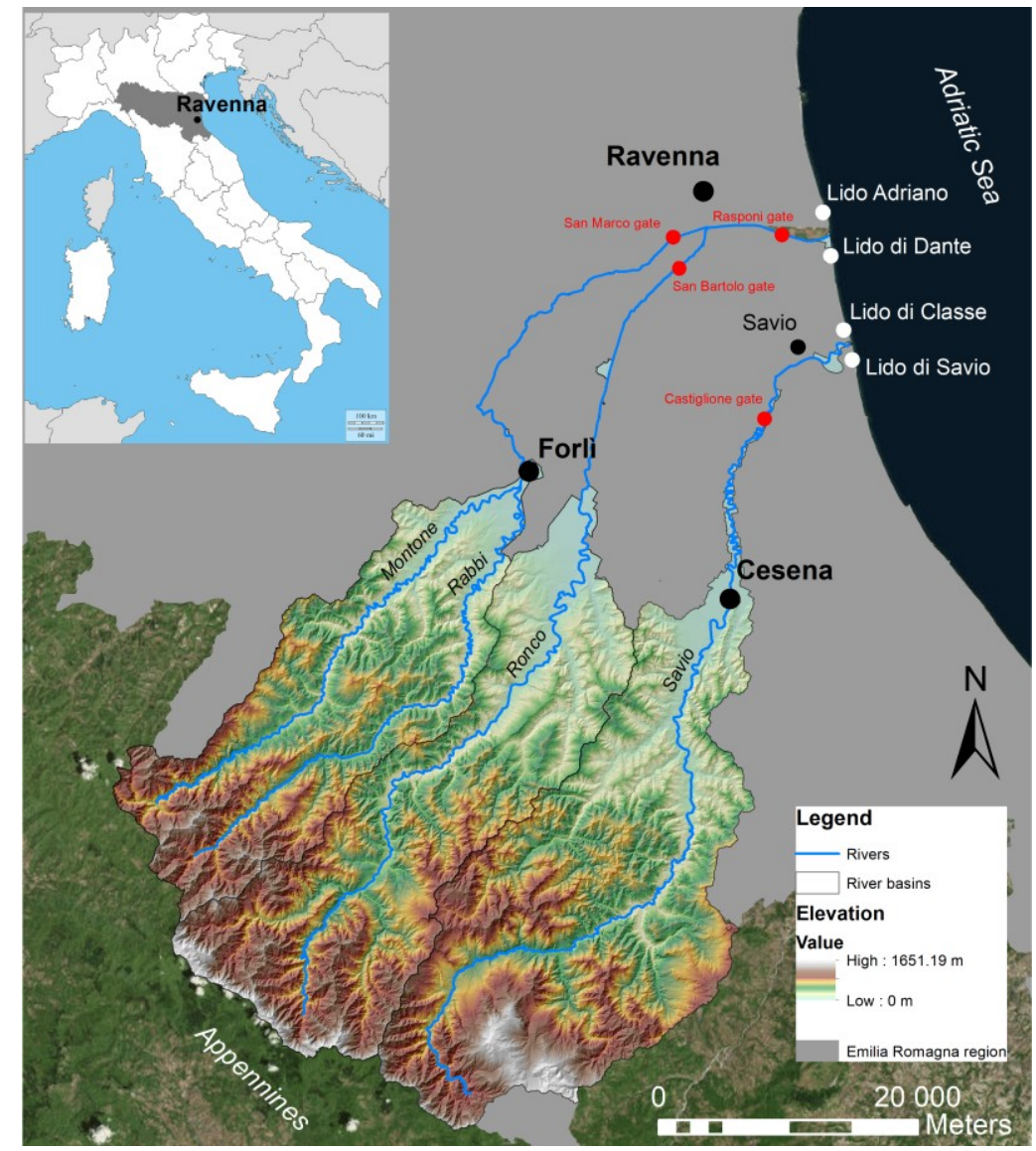

Fig. 1. Study area with location of the main artificial structures along the rivers

Both rivers exhibit a straight channel with rectangular cross-section in proximity of the monitoring stations. The maximum channel width is about $60 \mathrm{~m}$ in the Fiumi Uniti and 30 $\mathrm{m}$ in the Savio case. The stream bed gradient is $0.00029 \mathrm{~m} / \mathrm{m}$ in the Fiumi Uniti river [16] and $0.0003 \mathrm{~m} / \mathrm{m}$ in the Savio. Bed material is principally sandy: $D_{50}$ is around $0.55 \mathrm{~mm}$ in the Fiumi Uniti and around $0.50 \mathrm{~mm}$ in the Savio (i.e. medium to coarse sand).
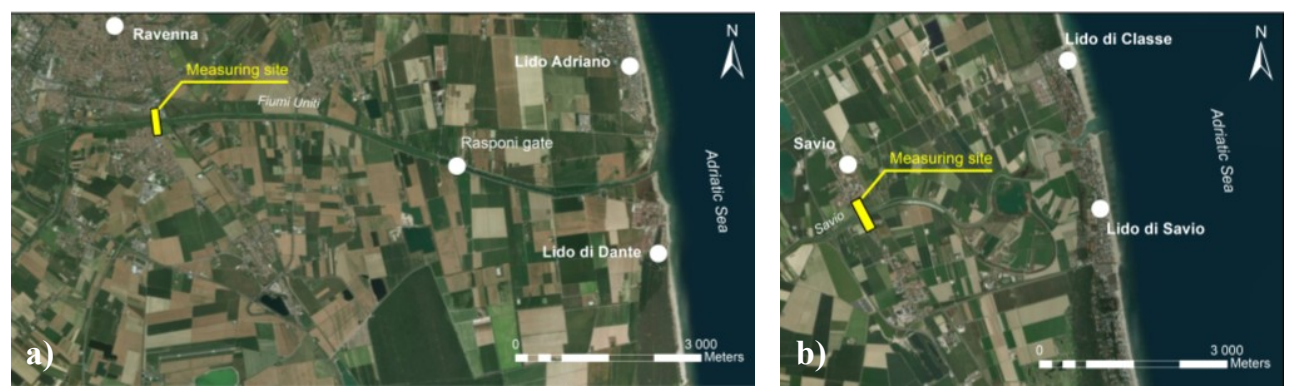

Fig. 2. Measuring sites: a) Fiumi Uniti; b) Savio. 


\section{Methodology}

The main research activity essentially included field bedload transport measurement and hydrodynamic modeling. Some of the bedload measurements were carried out in the years 2005-06 and other followed in 2017 and are still in progress. During floods, hydraulic and sediment transport data were collected at fixed verticals, equally spaced along the active cross section (i.e., the portion of the streambed which is actually contributing to bedload transport). Five and three verticals across the river cross-section were established for the Fiumi Uniti and Savio rivers, respectively. A standard USGS AA type current meter measured flow depth and flow velocity. A standard Helley-Smith bedload sampler (US BL84) with a $76 \times 76 \mathrm{~mm}$ intake and $0.1 \mathrm{~mm}$ of bag mesh was used for bedload transport sampling. A USGS A type wheel crane helped lowering all the instruments from the bridges. A staff gauge helped to visualize the water level changes. Bedload sampling time varied from 5 to 20 minutes per vertical. Each bedload sample, cleared from vegetation debris and exotic materials, was wet sieved to remove the incidentally present fraction finer than $63 \mu \mathrm{m}$ (which is considered as a wash-load contribution). The coarse fraction was then dry-sieved for 20 minutes with a standard Ro-Tap shaker and sieves arranged on a $1 / 2$ phi scale. Complementarily, hydrodynamic modeling was carried out to take into account any backwater effects due to the sluice gate dams (though they were kept constantly open) and the tidal effects (though almost negligible in the areas as the mean tidal range is $0.7 \mathrm{~m}$ ), and to simulate the hydraulic conditions of the monitored floods. Since the measuring sites show a prismatic channel and experience a slow flow rate changes during floods, a gradually varied flow conditions was assumed for the hydrodynamic simulation, resulting in a shear stress express as:

$$
\tau=\rho g H S
$$

where:

$\rho$ is the density of water;

$g$ is the gravity acceleration;

$H$ is the mean flow depth;

$S$ is the hydraulic gradient.

In particular, the threshold conditions of bedload transport have been examined considering three different approaches. The first refers to Shields's [19] incipient motion criterion, accounting for Brownlie [20] and Simoes [21] reinterpretations of the original Shield's diagram. In fact, as individual grain movement is function of sediment distribution as well as protrusion, packing and grading, they seems to be crucial in sediment transport initiation analysis $[22,23,24]$. Thus a second field-empirical based approach was taken into consideration, and in particular Carling [22] and Hammond [23] criteria. To notice that the first refers to gravel bed rivers while the second one refers to tidal channels. Despite these approaches result from different contest and hydrodynamic condition, compared to the current one, both of them evidence deviation from the Shields' curve. These criteria consider an empirical spurious power law function involving stress and representative sediment diameter:

$$
\tau_{c r}=a D^{b}
$$


where $a$ and $b$ are calibration coefficients [24] and D is the characteristic particle diameter of the sediment.

The latter is the critical stream power approach $\left(\omega_{c}\right)$, originally proposed by Bagnold [25] and revised by Parker et al. [26], in fact, although bed shear stress is widely used, the unit stream power is more strictly associated with sediment transport [26]. Bagnold's equation is the following one:

$$
\omega_{c}=2860.5 D^{1.5} \log (12 H / D)
$$

where:

$\mathrm{D}$ is the characteristic particle diameter of the sediment;

$\mathrm{H}$ is the water depth.

\section{Results}

Twelve floods were monitored at the Fiumi Uniti station and four on the Savio,. During all these floods the sluice gate dams were fully open. Only the floods with an almost unappreciable bedload transport are considered in this study (i.e. comparable to a possible threshold condition of sediment motion). In the Fiumi Uniti river, the weakest flood occurred on $11^{\text {th }}$ of November 2005 with a flow discharge of $17.27 \mathrm{~m}^{3} \mathrm{~s}^{-1}$ and a measured bedload lower than $0.06 \mathrm{~N} \mathrm{~m}^{-1} \mathrm{~s}^{-1}$. During this flood, the measured mean flow velocity was $0.374 \mathrm{~ms}^{-1}$, with a water depth of $1.31 \mathrm{~m}$.. In the Savio, the weakest flood occurred on $14^{\text {th }}$ of November 2017. Flow discharge was of $19.07 \mathrm{~m}^{3} \mathrm{~s}^{-1}$, corresponding to a bedload lower than $0.00016 \mathrm{~N} \mathrm{~m}^{-1} \mathrm{~s}^{-1}$, a mean flow velocity of $0.74 \mathrm{~ms}^{-1}$ and a water depth of $1.81 \mathrm{~m}$. This resulted in shear stresses of $1.73 \mathrm{Nm}^{-2}$ and $3.60 \mathrm{Nm}^{-2}$ for the Fiumi Uniti and the Savio, respectively. Threshold conditions of bedload transport were calculated according to the three different approaches herein considered (see paragraph 3). Referring to the Simoes criterion [21] a drag coefficient equal to 2.4 was assumed, referring to a mean grain size of $0.5 \mathrm{~mm}$. Concerning the second approach, Carling and Hammond equations were tested using $\mathrm{D}_{90}$ as a reference diameter. The use of $\mathrm{D}_{90}$ for Carling and Hammond criteria is in respect of their analysis, since in their studies only bigger particles were analyzed [22, 23]. In case of the third approach, based on the unit stream power, $\mathrm{D}_{50}$ was used calculating the threshold unit stream power value. Table 1 reports all these values along with our field results, also in terms of Shields mobility parameter $\left(\theta_{\mathrm{cr}}\right)$.

Table 1. Comparison of threshold sediment transport condition and field data.

\begin{tabular}{|c|c|c|c|c|}
\cline { 2 - 5 } \multicolumn{1}{c|}{} & $\boldsymbol{\tau}_{\text {FIUMI UNITI }}$ & $\boldsymbol{\theta}_{\text {cr }}$ & $\boldsymbol{\tau}_{\text {SAVIO }}$ & $\boldsymbol{\theta}_{\text {cr }}$ \\
\cline { 2 - 5 } & {$\left[\mathbf{N} / \mathbf{m}^{2}\right]$} & {$[-]$} & {$\left[\mathbf{N} / \mathbf{m}^{2}\right]$} & {$[-]$} \\
\hline Field data & 1.73 & 0.22 & 3.60 & 0.42 \\
\hline Shields-Brownlie & 0.47 & 0.05 & 0.42 & 0.05 \\
\hline Shields-Simoes & 1.38 & 0.10 & 1.41 & 0.11 \\
\hline Carling & 4.55 & 0.29 & 4.36 & 0.31 \\
\hline Hammond et al. & 2.07 & 0.13 & 1.98 & 0.14 \\
\hline Bagnold-Parker & 1.23 & 0.33 & 1.95 & 0.46 \\
\hline
\end{tabular}

Fig. 3 reports different criteria on $\theta_{\mathrm{cr}}-\mathrm{vs}-\mathrm{Re}^{*} \log -\log$ plotting chart; in particular the actual field observation are plotted accounting for both $\mathrm{D}_{50}$ and $\mathrm{D}_{90}$ (see Table 2). 
Table 2. Shields' parameters calculated with $\mathrm{D}_{50}$ and with $\mathrm{D}_{90}$ referred to both rivers.

\begin{tabular}{|c|c|c|c|c|}
\hline & \multicolumn{2}{|c|}{$\mathbf{D}_{\mathbf{5 0}}$} & \multicolumn{2}{c|}{$\mathbf{D}_{\mathbf{9 0}}$} \\
\hline & Re$^{*}$ & $\boldsymbol{\theta}_{\text {cr }}$ & Re$^{*}$ & $\boldsymbol{\theta}_{\text {cr }}$ \\
\hline Fiumi Uniti & 21.83 & 0.20 & 40.69 & 0.11 \\
\hline Savio & 29.78 & 0.45 & 52.65 & 0.25 \\
\hline
\end{tabular}

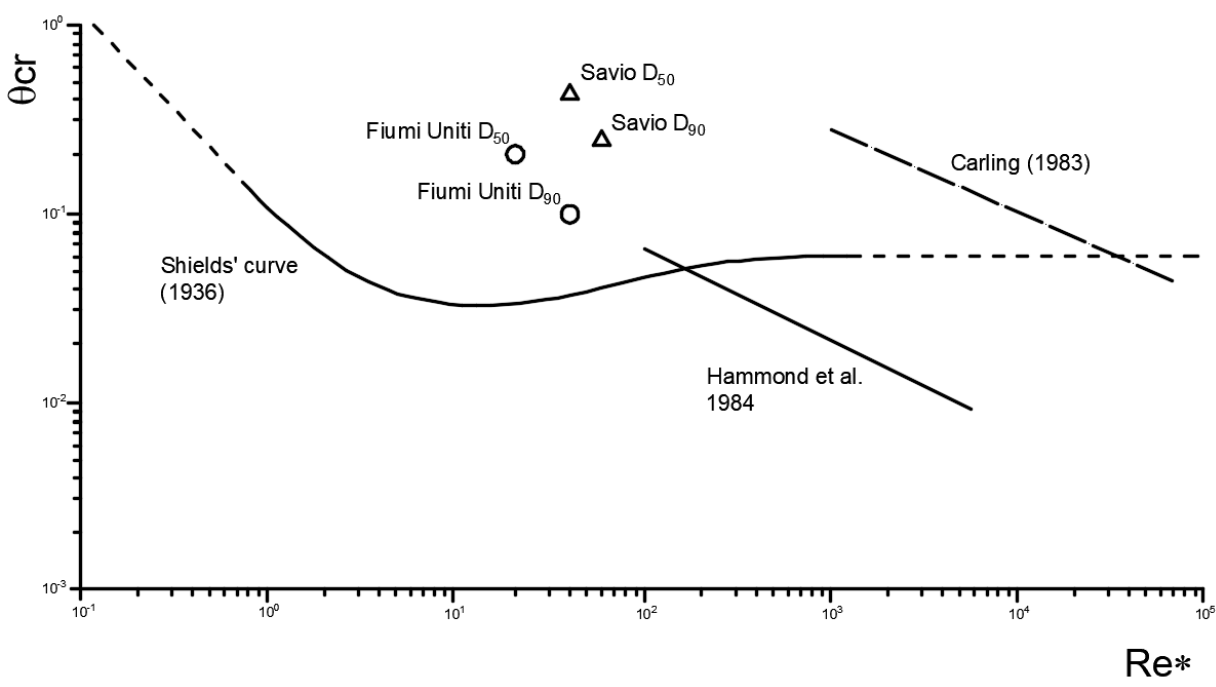

Fig. 3. Fiumi Uniti and Savio river field data compared with Shields [19] and Carling, Hammond et al. [23] criteria.

\section{Discussion}

The sediment transport condition of sediment motion analyzed and reported in Table 1 puts in evidence a significant inaccurate estimation of critical shear stress values, compared to the field data. Moreover considering the results related to the Shields dimensionless parameter $\theta_{\text {cr }}$, all criteria show a big difference in values (i.e. across an order of magnitude), except for Bagnold (modified by Parker) and Carling. Shields and revised Shields criteria (Brownlie and Simoes) evidence their non-applicability, especially explained by the low value of $\theta_{\text {cr }}$ respect the ones obtained from field data. Shields approach is mainly based on single grained sediment and does not consider irregularly shaped grains. Instead the criterion of Carling takes into account factors like grain size, grading, packing and protrusion which are completely excluded in Shields and revised Shields criteria. Moreover it is referred to narrow (aspect ratio < 11) gravel (or even coarser) bed steep channels, and it may leads to the reported discrepancies with our field data. Also Hammond et al. criterion consider protrusion and packing factors but their model was implemented on small tidal estuaries with a bi-modal, gravel-prevailing, bed. As far as Bagnold criterion is concerned, Parker already puts noticed that the unit stream power is more variable with slope than critical mean shear stress. And even if the shear stress values calculated with Bagnold 
criterion still differs from our field data, the critical Shields parameter value $\left(\theta_{\mathrm{cr}}\right)$ seems reasonable.

\section{Final remarks}

The aim of this research, as part of a regional scale project, is to widen the dataset of river sediment supply to the Emilia-Romagna beaches, which are affected by severe erosion. Bedload measurement campaigns carried out in the Fiumi Uniti and Savio rivers allowed to estimate the critical shear stress for bed material incipient motion in sandy-bed rivers. The definition incipient motion condition obtained from field data was compared with wellknown criteria available in literature, such as the classical Shields approach as well as alternative methods. The results identified a noticeable difference between field, theoretically computed critical values. These differences are still under investigation. Further studies are necessary, possibly including the bed roughness effect due to the presence of moving bedforms.

\section{References}

1. L. Calabrese, S. Lorito. Mappatura della linea di riva da foto aerea. In: Perini, L., Calabrese, L. (Eds.), Il sistema mare-costa dell'Emilia-Romagna. Pendragon, Bologna, Italy, 43-56. (2010)

2. C. Armaroli, P. Ciavola, L. Perini, S. Lorito, A. Valentini, M. Masina. Critical storm thresholds for significant morphological changes and damage along the EmiliaRomagna coastline, Italy. Geomorphology 143-144, 34-51 (2012)

3. J. D. Milliman, J. P. M. Syvitski. Geomorphic tectonic control of sediment discharge to the ocean: the importance of small mountainous rivers. J. Geol. 100, 525-544. (1992)

4. D.L. Inman, S.A. Jenkins. Climate change and episodicity of sediment flux of small California rivers. J. Geol. 107, 251-270. (1999)

5. D. L. Inman, S. A. Jenkins. The Nile littoral cell and man's impact on the coastal zone of the southeastern Mediterranean. Proc. 19th Conf. Coastal Engineering Conf, Amer. Soc. Civil Eng., 2, 1600-1617. (1984)

6. D. L. Inman. Budget of sand southern California: river discharge vs cliff erosion. Proc. from a Conference on Coastal Erosion, California Coastal Commission, 10-15. (1985)

7. G.M. Kondolf. Hungry water: effects of dams and gravel mining on river channels. Environ. Manage. 21 (4), 533-551. (1997)

8. F. Liebault, H. Piegay. Assessment of channel changes due to long-term bedload supply decrease, Roubion River, France. Geomorphology 36, 167-186. (2001)

9. G.E. Grant, J.C. Schmidt, S.L. Lewis. A geological framework for interpreting downstream effects of dams on rivers. In: O'Connor, J.E. \& Grant G.E. (eds): A Peculiar River: Geology, Geomorphology, and Hydrology of the Deschutes River, Oregon. Water Sci. Appl. 7, 203-219. (2003)

10. J.M. Hooke. Human impacts on fluvial systems in the Mediterranean region. Geomorphology 79, 311-335. (2006)

11. E.J. Anthony. The Human influence on the Mediterranean coast over the last 200 years: a brief appraisal from a geomorphological perspective. Geomorphologie 20 (3), 219-226. (2014) 
12. P. Billi, M. Fazzini. Global change and river flow in Italy. Global Planet. Change. 155C, 234-246. (2017)

13. P. Billi, E. Salemi. Misura delle portate solide in sospensione al fondo del F. Reno. Arpa Rivista, supplemento al n.6, 8-15. (2004)

14. P. Ciavola, P. Billi, C. Armaroli, E. Preciso, E. Salemi, Y. Balouin. Morphodynamics of the Bevano Stream outlet: the role of bedload yield. Geologia Tecnica e Ambientale 1, 41-57. (2005)

15. P. Ciavola, E. Salemi, P. Billi. Sediment supply and morphological evolution of a small river mouth (Fiumi Uniti, Ravenna, Italy): should river management be storm-driven? In: Barazzutti, M., Marabini, F. China-Italy Bilateral Symposium on the Coastal Zone and Continental Shelf Evolution Trend. 104-113, Bologna, Albisani Editore (2010)

16. P. Billi, E. Salemi, E. Preciso, P. Ciavola, C. Armaroli. Field measurement of bedload in a sand-bed river supplying a sediment starving beach. Zeitschrift für Geomorphologie. (2017)

17. A. Amorosi, M.C. Centineo, E. Dinelli, F. Lucchini, F. Tateo. Geochemical and mineralogical variations as indicators of provenance changes in Late Quaternary deposits of SE Po Plain. Sed. Geol. 151, 273-292 (2002)

18. C. Mennella. Il clima d'Italia: volume secondo, F.lli Conte Editori, Napoli, Italia. (1972)

19. A. Shields. Application of Similarity Principles and Turbulence Research to Bed-Load Movement. California Institute of Technology, Pasadena (Translated from German). (1936)

20. W. R. Brownlie. Prediction of flow depth and sediment discharge in open channels. Report No. KH-R-43A, California Institute of Technology, W. M. Keck Laboratory, Pasedena, CA, 232 pp. (1981)

21. J.M. Simoes. Shear velocity criterion for incipient motion of sediment. Water Sci. Eng. 7(2), 183-193. (2014)

22. P.A. Carling. Threshold of coarse sediment transport in broad an narrow natural streams. Earth Surf. Processes 8, 1-18. (1983)

23. F.D.C. Hammond, A.D. Heathershaw, D.N. Langhorne. A comparison between Shields' threshold criterion and the movement of loosely packed gravel in a tidal channel. Sedimentology 31, 51-62. (1984)

24. M.S. Lorang, F. R. Hauer. Flow competence and streambed stability: an evaluation of technique and application. J. N. Am. Benthol. Soc. 22(4), 475-491. (2003)

25. R. A. Bagnold. An empirical correlation of bedload transport rates in flumes and natural rivers. Proc. of the Royal Society of London A372,453-473. (1980)

26. C. Parker, N. J. Clifford, C.R. Thorne. Shear velocity criterion for incipient motion of sediment. Geomorphology. 126, 51-56. (2011)

27. P.Y. Julien. Erosion and sedimentation. Cambridge University Press, Cambridge. (1995)

28. E.J. Hickin. River Geomorphology. http://www.sfu.ca/ hickin/RIVERS , 70-107. (2010) 